\title{
Platelet adhesiveness, plasma free fatty acids, and serum triglycerides in kwashiorkor
}

\author{
M. KHALIL, M. K. AREF, S. MAHMOUD, A. T. ABDEL-MALEK, F. K. GUIRGIS, \\ M. MOGHAZY, and M. M. ABDEL-HAY \\ From the Departments of Paediatrics and Clinical Pathology, Faculty of Medicine, University of Alexandria, \\ Egypt
}

\begin{abstract}
Khalil, M., Aref, M. K., Mahmoud, S., Abdel-Malek, A. T., Guirgis, F. K., Moghazy, M., and Abdel-Hay, M. M. (1974). Archives of Disease in Childhood, 49, 568. Platelet adhesiveness, plasma free fatty acids, and serum triglycerides in kwashiorkor. The concentrations of plasma free fatty acids and triglycerides were studied in 15 cases of kwashiorkor and in 14 normal controls in relation to the degree of platelet adhesiveness. A significant rise in the level of free fatty acids was found which correlated with a significant increase in platelet adhesiveness in these cases.
\end{abstract}

In 1959, McDonald and Edgill reported a decrease in platelet adhesiveness after 4 to 5 weeks of treatment with a fat-free diet in patients with ischaemic heart disease. Additional evidence of the effects of blood lipids on human platelets has been reported by Mustard and Murphy (1962), who found that a diet rich in fat caused an increase in platelet clumping with diminished platelet survival time. In kwashiorkor, disturbances in fat metabolism, with abnormal variation in the level of different lipid constituents, have been recognized by various workers (Schwartz and Dean, 1957; Lewis et al., 1964; Awwaad et al., 1967; Khalil et al., 1973).

Sandstead et al. (1965) reported that petechial haemorrhages occur frequently in kwashiorkor. Though the mechanism of this haemostatic disturbance could be partially attributed to a nutritional vascular defect, possible derangement of platelet function in the presence of lipid disturbance was worthy of investigation. The present work accordingly deals with the study of the plasma levels of free fatty acids and triglycerides and their relation to platelet adhesiveness in kwashiorkor.

\section{Material and methods}

The study was made on 15 infants ( 7 males, 8 females) suffering from kwashiorkor, together with a matching normal control group of 14 apparently well-nourished infants. Their ages ranged from 8 to 22 months. The criteria for the diagnosis of kwashiorkor included growth

Received 28 December 1973. failure (weight between $60 \%$ and $80 \%$ of the expected weight for age), oedema, muscle wasting with retention of some subcutaneous fat, and psychomotor changes (Jelliffe, 1966). Other signs such as skin lesions, hair changes, and hepatomegaly were also commonly encountered.

The following laboratory investigations were carried out. Total serum proteins, albumin, and globulin levels (Varley, 1967); plasma free fatty acids (Duncombe, 1963); serum triglycerides (Van Handel and Zilversmit, 1957); platelet adhesiveness (glass beads, modified Hellem's method (Hellem and Stormorken, 1960)).

\section{Results}

Platelet adhesiveness in normal controls varied between 14 and $44 \%$ (mean $25 \cdot 6 \pm 6 \cdot 1 \%$ ). In kwashiorkor the range was between 41 and $55 \%$ (mean $47 \cdot 5 \pm 4 \cdot 0 \%$ ). The increase is significant $(\mathrm{P}<0 \cdot 01)$.

The values in Table I indicate that infants with kwashiorkor showed statistically significant variations from normal controls in the levels of plasma free fatty acids, serum triglycerides, and total serum proteins, as well as in the level of serum albumin and globulins. While there is a significant rise in the level of plasma free fatty acids in kwashiorkor, there is a significant reduction in the serum levels of triglycerides, total proteins, albumin, and globulins.

Table II shows that in cases of kwashiorkor there was a positive correlation between platelet adhesiveness and plasma free fatty acids. No such cor- 
TABLE I

Levels of free fatty acids (FFA), triglycerides (TG), total proteins, albumin, and globulins in plasma of patients with kwashiorkor and of normal controls

\begin{tabular}{|c|c|c|c|c|c|c|c|c|c|c|}
\hline & \multicolumn{5}{|c|}{$\begin{array}{l}\text { Normal controls } \\
\quad(14 \text { cases })\end{array}$} & \multicolumn{5}{|c|}{$\begin{array}{l}\text { Kwashiorkor } \\
(15 \text { cases })\end{array}$} \\
\hline & FFA & TG & $\underset{\text { proteins }}{\text { Serum }}$ & Albumin & Globulins & FFA & TG & $\underset{\text { proteins }}{\text { Serum }}$ & Albumin & Globulins \\
\hline & $\mu \mathrm{Eq} / 1$ & $\mathrm{mg} / 100 \mathrm{ml}$ & $\mathrm{g} / 100 \mathrm{ml}$ & $\mathrm{g} / 100 \mathrm{ml}$ & $\mathrm{g} / 100 \mathrm{ml}$ & $\mu \mathrm{Eq} / 1$ & $\mathrm{mg} / 100 \mathrm{ml}$ & $\mathrm{g} / 100 \mathrm{ml}$ & $\mathrm{g} / 100 \mathrm{ml}$ & $\mathrm{g} / 100 \mathrm{ml}$ \\
\hline $\begin{array}{l}\text { Mean } \\
\text { Range } \\
\text { SD } \\
\text { SE }\end{array}$ & $\begin{array}{l}236 \cdot 8 \\
85-420 \\
98 \cdot 9 \\
26 \cdot 4\end{array}$ & $\begin{array}{c}76 \cdot 7 \\
45-105 \\
19 \cdot 69 \\
6 \cdot 95\end{array}$ & $\begin{array}{c}6 \cdot 68 \\
6 \cdot 0-7 \cdot 8 \\
0.63 \\
0 \cdot 168\end{array}$ & $\begin{array}{c}4 \cdot 35 \\
3 \cdot 5-5 \cdot 3 \\
0 \cdot 53 \\
0 \cdot 140\end{array}$ & $\begin{array}{c}2 \cdot 33 \\
2 \cdot 0-3 \cdot 3 \\
0 \cdot 39 \\
0 \cdot 104\end{array}$ & $\begin{array}{c}572 \cdot 0 \star \\
315-1000 \\
173 \cdot 49 \\
44 \cdot 8\end{array}$ & $\begin{array}{c}44 \cdot 7^{\star} \\
30-72 \\
12 \cdot 88 \\
4 \cdot 55\end{array}$ & $\begin{array}{c}3 \cdot 54^{\star} \\
2 \cdot 5-4 \cdot 9 \\
0 \cdot 76 \\
0 \cdot 19\end{array}$ & $\begin{array}{c}2 \cdot 03^{\star} \\
1 \cdot 2-2 \cdot 9 \\
0 \cdot 54 \\
0 \cdot 14\end{array}$ & $\begin{array}{c}1 \cdot 51^{\star} \\
0.9-2 \cdot 2 \\
0 \cdot 41 \\
0 \cdot 106\end{array}$ \\
\hline
\end{tabular}

^Significant difference $(P<0.01)$ between controls and kwashiorkor cases.

TABLE II

Correlation between platelet adhesiveness and both plasma free fatty acids and serum triglycerides in cases of kwashiorkor

\begin{tabular}{c|c|c}
\hline & $\begin{array}{c}\text { Platelet adhesiveness } \\
\text { and plasma free fatty } \\
\text { acids }\end{array}$ & $\begin{array}{c}\text { Platelet adhesiveness } \\
\text { and } \\
\text { serum triglycerides }\end{array}$ \\
\hline $\mathrm{r}$ & 0.70 & 0.044 \\
$\mathrm{t}$ & 3.52 & 0.090 \\
$\mathrm{P}$ & $<0.005$ & $>0.05$ \\
\hline
\end{tabular}

relation between platelet adhesiveness and serum triglycerides was shown.

\section{Discussion}

The factors which have been recognized to influence platelet adhesiveness include the blood lipids. Increased platelet adhesiveness after high saturated fatty acid meals in normals and in patients with diabetes mellitus and coronary heart disease were reported by Moolten, Jenning, and Solden (1963). An increase in platelet adhesiveness during alimentary lipaemia was also shown by Philp and Wright (1965). Warner, Hoak, and Conner (1967) found that plasma concentration of free fatty acids was high in patients with high frequency of thromboembolic complications.

In kwashiorkor disturbances in fat metabolism were recognized by various investigators. A decrease in total blood lipids was reported by Schwartz and Dean (1957) and Cravioto, Pena, and Burgos (1959). Lewis et al. (1964), Awwaad et al. (1967), and Khalil et al. (1973) reported a decrease in total serum cholesterol, and reduction in the level of both $\alpha$-lipoproteins (Cravioto et al., 1959) and $\beta$-lipoproteins (Khalil et al., 1973) was also shown. In addition to the dietary deficiency of lipids, disturbances in the protein transport system, the concomitant impairment of absorption and increased loss of fat in stools are considered the main factors underlying these disturbances of blood lipids.

In the present study the level of the plasma free fatty acids in kwashiorkor was significantly higher than in normal controls. This agrees with the results of Lewis et al. (1964) who found plasma free fatty acid levels significantly raised in severe cases of kwashiorkor. Sakr et al. (1971), in their study of serum lipids in protein-calorie malnutrition, found an increase in the serum saturated and a decrease in unsaturated fatty acids in cases of kwashiorkor. They attributed these changes to the inadequacy of essential fatty acids in diets of these cases, with selective mobilization of saturated fatty acids from depots and selective deposition of unsaturated fatty acids in the liver. In the present investigation we furthermore found a significant increase in platelet adhesiveness in cases of kwashiorkor compared with controls, which could be attributed to the reported significant rise in the level of plasma free fatty acids.

Warner et al. (1967) found that the incidence of thrombi was higher in patients with free fatty acid levels greater than $750 \mu \mathrm{Eq} / 1$. than in patients with lower levels. In the present study the mean value of the level of free fatty acids was $572 \mu \mathrm{Eq} / \mathrm{l}$. which may explain why thromboembolic manifestations are uncommon in cases of kwashiorkor in spite of the increased platelet adh $\epsilon$ siveness in these cases.

In this study the level of plasma triglycerides was significantly reduced in cases of kwashiorkor. This agrees with the result of Lewis et al. (1964) who reported a significant reduction in plasma triglycerides in their kwashiorkor cases. The same mechanisms (deficiency of dietary fat and impaired fat absorption) which are involved in the reduction of cholesterol and phospholipids could be the underlying factors for hypotriglyceridaemia in these 
malnourished infants. The effect of lipids on platelet adhesiveness is attributed mainly to the level of free fatty acids in the plasma which possibly produces morphological changes in the platelet membrane (Hoak et al., 1972). Reduction of other lipid constituents, however, seems to have little effect.

\section{REFERENCES}

Awwaad, S., Essawy, M., Awadalla, M., and Abdel-Wahab, E. (1967). Serum lipids in kwashiorkor in Egyptian children. Gazette of the Egyptian Paediatric Association, 15, 81.

Cravioto, J., Pena, C. L., and Burgos, G. (1959). Fat metabolism in chronic, severe malnutrition: lipoprotein in children with kwashiorkor. Metabolism, 8, 722 .

Duncombe, W. G. (1963). The colorimetric micro-determination of long-chain fatty acids. Biochemical fournal, 88, 7.

Hellem, A. J., and Stormorken, H. (1960). Platelet adhesionaggregation reaction and its clinical significance. In Recent Advances in Blood Coagulation, p. 69. Ed. by L. Poller. Churchill, London.

Hoak, J. C., Spector, A. A., Fry, G. L., and Barnes, B. C. (1972). Localization of free fatty acids taken up by human platelets. Blood, 40, 16.

Jelliffe, D. B. (1966). The assessment of the nutritional status of the community. W.H.O. Monograph Series, 53, 186.

Khalil, M., Aref, M. K., Abdel-Malek, A. T., Moghazy, M., and El-Lozy, M. (1973). The effect of diarrhoea on low density beta lipoproteins and cholesterol in protein calorie malnutrition. fournal of Tropical Medicine and Hygiene, 76, 71.

Lewis, B., Hansen, J. D. L., Wittman, W., Krut, L. H., and Stewart, F. (1964). Plasma free fatty acids in kwashiorkor and the pathogenesis of the fatty liver. American fournal of Clinical Nutrition, 15, 161.
McDonald, L., and Edgill, M. (1959). Changes in coagulability of the blood during various phases of ischaemic heart-disease. Lancet, 1, 1115.

Moolten, S. E., Jenning, P. B., and Solden, A. (1963). Dietary fat and platelet adhesiveness in arteriosclerosis and diabetes. American fournal of Cardiology, 11, 290.

Mustard, J. F., and Murphy, E. A. (1962), Effect of different dietary fats on blood coagulation, platelet economy, and blood lipids. British Medical fournal, $1,1651$.

Philp, R. B., and Wright, H. P. (1965). Effect of adenosine on platelet adhesiveness in fasting and lipaemic bloods. Lancet, 2, 208.

Sakr, R., El-Hawary, M. F. S., Samuel, S., and Hiskial, N. (1971). Total lipids fatty acids per cent composition in plasma and R.B.C. in protein calorie malnutrition in U.A.R. Gazette of the Egyptian Paediatric Association, 19, 61.

Sandstead, H. H., Shukry, A. S., Prasad, A. S., Gabr, M. K., Hifney, A. E., Mokhtar, N., and Darby, W. J. (1965). Kwashiorkor in Egypt. Clinical and biochemical studies. American fournal of Clinical Nutrition, 17, 15.

Schwartz, R., and Dean, R. F. A. (1957). The serum lipids in kwashiorkor. Fournal of Tropical Pediatrics, 3, 23.

Van Handel, E., and Zilversmit, D. B. (1957). Micromethod for the direct determination of serum triglycerides. Fournal of Laboratory and Clinical Medicine, 50, 152.

Varley, H. (1967). The plasma proteins. Section II. The biuret method; method of Reinhold (1953). In Practical Clinical Biochemistry, 4th ed., p. 236. Heinemann, London.

Warner, E. D., Hoak, J. C., and Connor, W. E. (1967). The role of fatty acids in platelet aggregation and thrombosis. In Platelets: Their Role in Hemostasis and Thrombosis, p. 249. Ed. by K. M. Brinkhous, I. S. Wright, J. P. Soulier, H. R. Roberts, and S. Hinnom. (Thrombosis et Diathesis Haemorrhagia, Suppl. 26.) Schattauer, Stuttgart.

Correspondence to Professor M. Khalil, 66 Horreya Road, Alexandria, Egypt. 